\title{
Dirty Hands and Moral Injury ${ }^{1}$
}

\section{Q1 JOSEPH WIINIKKA-LYDON}

\begin{abstract}
Moral injury describes the effects of violence on veterans beyond what trauma discourse can describe. I put moral injury in conversation with a separate but related concept, dirty hands. Focusing on Michael Walzer's framing of dirty hands and Jonathan Shay's understanding of moral injury, I argue that moral injury can be seen as part of the dirt of a political leader's dirty hands decisions. Such comparison can focus more attention on the broader institutional context in which such dirty hands decisions are executed, while contributing to the growing vocabulary of moral conflict, trauma, and harm.
\end{abstract}

'No judge will ever undertake to strangle with his own hands the man whom he has condemned to death.'

$$
\text { - Leo Tolstoy, What I Believe }{ }^{2}
$$

In the following pages I place moral injury into conversation with dirty hands. Drawn from the behavioral sciences and from political and moral philosophy respectively, both articulate the tragic nature of high stakes politics and war. They concern the ways in which violence can seem to harm one's very character and how politics itself, including political violence and war, may demand one to sacrifice their moral integrity for the greater good. These two concepts are important to several academic fields yet, because they concern tragedy, experience, and even hope, have entered into popular speech. Such a comparison, then, can help not only with academic discussions but, if we take seriously the idea that war is the continuation of politics by other means, can also help a broader audience better understand the ways politics and explicit political violence can transform moral being. ${ }^{3}$

1 I am grateful to Joshua Daniels for his feedback, as well as conversations with Matej Cíbik and Michael Campbell. This publication was supported within the project of Operational Programme Research, Development and Education (OP VVV/OP RDE), 'Centre for Ethics as Study in Human Value', registration No. CZ.02.1.01/0.0/0.0/15_003/ 0000425, co-financed by the European Regional Development Fund and the state budget of the Czech Republic.

2 What I Believe, (New York: Cosimo, 2009), 44.

3 Carl von Clausewitz, On War (Princeton, N.J.: Princeton University Press, 1989), 87. 


\section{Joseph Wiinikka-Lydon}

There are many approaches, however, to both dirty hands and moral injury. I focus on two writers who are seminal to notions of dirty hands and moral injury, Michael Walzer and Jonathan Shay, respectively. ${ }^{4}$ Walzer, a philosopher, and Shay, a psychiatrist, are often seen as the originators of both discourses, and beyond this, they continue to have a significant and unique influence of their respect discourses. Shay continues to have broad influence across multiple disciplines where moral injury is engaged. ${ }^{5}$ And Walzer's framing continues, decades later, to frame assumptions in dirty hands discourse. ${ }^{6}$ Indeed, Walzer's article can be seen as the 'paradigm case of dirty hands.' 7

Paradigm, however, is not the only reason to focus on their work. Walzer and Shay frame their relevant concepts in ways that can help further understanding of both terms. Moral injury, for example, helps highlight overlooked aspects of dirty hands scenarios and the

4 Moral injury is not a new term to philosophy. It goes back at least to the debates between Jeffrie Murphy and Jean Hampton on retributive justice, who were indebted to Joseph Butler [Jeffrie G. Murphy and Jean Hampton, Forgiveness and Mercy (New York: Cambridge University Press, 1988)]. This understanding of moral injury, however, is almost the mirror opposite of how it has developed in psychology since Jonathan Shay's early writing, as it focuses on the suffering of 'victims' as opposed to 'perpetrators' [Joseph Wiinikka-Lydon, 'Mapping Moral Injury: Comparing Discourses of Moral Harm', Fournal of Medicine and Philosophy (forthcoming).]

5 Rita Nakashima Brock and Gabriella Lettini, Soul Repair: Recovering from Moral Injury after War (Boston: Beacon Press, 2012); Kinghorn, Warren, 'Combat Trauma and Moral Fragmentation: A Theological Account of Moral Injury', Fournal of the Society of Christian Ethics 32(2) (2013), 57-74; Sherman, Nancy, Afterwar: Healing the Moral Wounds of Our Soldiers (New York: Oxford University Press, 2015); WiinikkaLydon op. cit. note 4; 'Moral Injury as Inherent Political Critique: The Prophetic Possibilities of a New Term', Political Theology 18(3) (2016), 219-232.

6 Demetris Tillyris, "Learning How Not to Be Good': Machiavelli and the Standard Dirty Hands Thesis', Ethical Theory and Moral Practice 18 (2015), 61-74, 62fn1; C.A.J. Coady, 'Terrorism, Morality, and Supreme Emergency', Ethics 114(4) (2004), 772-89.

7 Stephen De Wijze, 'The Real Issues Concerning Dirty Hands: A Response to Kai Nielsen', South African Fournal of Philosophy 15(4) (1996), 149-51, 2; Nielsen, 'There Is No Dilemma of Dirty Hands', in Igor Primoratz (ed.), Politics and Morality, (London: Palgrave Macmillan, 2007), 20-37. De Wijze and Nielsen agree on this, even though they have central disagreements with each other's work. 


\section{Dirty Hands and Moral Injury}

larger ecology in which dirty hands takes place. Moral injury can also be seen in dirty hands discourse as one of the results of dirty hands decisions, a form of the dirt that certain political decisions that are wrong but necessary create. The dirty hands decisions of leaders, in other words, can create moral injury, a lasting feeling of moral disability, in those who must carry out a leader's decisions. Conversely, Walzer's understanding of dirty hands, by virtue of its focus on decision makers and political leaders, can call attention to the possibility of a more ecological understanding of moral injury. ${ }^{8}$ The view of suffering held by many moral injury writers focuses on the individual soldier or the role of the soldier, concerned as they have been with clinically treating moral injury as a psychological disorder. Expanding this to see moral injury not as a discreet, delimited experience but, instead, a suffering that arises from the environment created through political violence and shared by those within such environments, could help not only in better theorizing moral injury but in therapeutic interventions by reframing the source and nature of the suffering.

This essay begins by defining moral injury and dirty hands according to Shay and Walzer, followed by a more in depth comparison. It ends with a final constructive piece where I make an argument for moral injury as part of the dirt of dirty hands. Central to this comparison will be trying to create a better understanding of dirty hands as a tragic ecology by including the conceptual insights of moral injury discourse. To do this, I analyze in both thinkers issues of leadership and how the decisions of leadership affects those who carry out commands (hierarchy); how the guilt or shame of a leader relates to that of subalterns (issues of culpability); and the subjective experience and emotions involved in the 'dirt' or 'injury' and the contexts in which

8 It should be said that several writers have argued that dirty hands be deployed beyond politics since Walzer's formative essay, although I keep Walzer's more narrow understanding in order to begin work on comparisons with moral injury See C.A.J. Coady and Onora O'Neill, 'Messy Morality and the Art of the Possible', Proceedings of the Aristotelian Society, Supplementary Volumes 64 (1990), 259-294; Stephen De Wijze op. cit., note 7, 149-51; Kai Nielsen, 'There is No Dilemma of Dirty Hands: Response to Stephen de Wijze', South African Fournal of Philosophy 15(4) (1996); Michael Stocker, 'Dirty Hands and Ordinary Life', in Paul Rynard and David Shugarman (eds.), Cruelty and Deception: The Controversy over Dirty Hands in Politics (Peterborough, Ontario: Broadview Press, 2000). Although Walzer says in his original article that he does not limit dirty hands to only the political sphere, his work heavily focuses on the political. See Michael Walzer, Fust and Unjust Wars: A Moral Argument with Historical Illustrations (New York: Basic Books, 2015). 


\section{Joseph Wiinikka-Lydon}

such harms are created (environment and location). The overall goal of these pages, then, is for such work to help further clarify both concepts and, in so doing, contribute not only to discussions of dirty hands but help strengthen the larger, and growing, interdisciplinary vocabulary for articulating moral conflict, dilemma, and harm.

\section{Defining Dirty Hands and Moral Injury}

Walzer frames dirty hands as a 'moral dilemma', a situation where one must choose between two options 'both of which would be wrong for him to undertake. ${ }^{9}$ As the discussion of this concept has progressed in philosophy, dirty hands has come to refer to those times when a political leader must choose a course of action that is morally wrong in order to achieve some greater good. There is as C.A.J. Coady notes a good deal of necessity inherent in this understanding of dirty hands, where the politician, if she were to stick to her moral principles and did not commit the wrong, would allow something much worse to occur, thus necessitating wrongdoing in the service of the greater good. ${ }^{10}$ Central to this, however, is action taken that is knowingly evil to some degree, or at least perceived to be off limits ordinarily. In other words, one chooses to put their hands in the dirt, but the dire moral dimension of the situation also seems to demand one's self-inflicted impurity done consciously.

Turning to Shay's understanding of moral injury, he initially refers to the phenomenon as the 'undoing of character' or the 'ruin of good character' through 'lifelong disabling psychiatric symptoms caused by "catastrophic war experiences."' 11 Although in this early definition moral injury is said to 'ruin' character itself, I would also allow within the definition of moral injury the individual's subjective sense that they are no long 'good' persons, can no longer pursue the good, or that the world is bereft of goodness or its possibility, even if objective observers or those close to the morally injured person

9 Michael Walzer, 'Political Action: The Problem of Dirty Hands', Philosophy and Public Affairs 2(2) (1973), 160-80, 160.

10 Coady op. cit. note 6, 779 .

11 Jonathan Shay, 'Learning About Combat Stress from Homer's Iliad', Fournal of Traumatic Stress 4(4) (1991), 561-79, 563; Jonathan Shay, Achilles in Vietnam: Combat Trauma and the Undoing of Character (New York: Simon \& Schuster, 1995), xiii. 


\section{Dirty Hands and Moral Injury}

would say the person still has a good character. ${ }^{12}$ What is crucial for the definition, however, is that the individual experiences such a moral fall. They feel that they are no longer able to successfully strive toward certain expectations of what it is to be a good person. ${ }^{13}$ In other words, having carried out the duties of the soldier, they feel they are no longer capable - emotionally, cognitively - of fulfilling the roles of parent, family member, community member, or citizen, among others. ${ }^{14}$

Walzer's emphasis on leadership also matches well with that of Shay, who in his original formulation of moral injury defines it in terms of leadership and the chain of command. Shay argues that moral injury arises when a soldier's 'moral order' is shaken after perceiving that their commander has betrayed what is right. He argues specifically that moral injury occurs when '(1) there has been a betrayal of what's right [according to the soldier] (2) by someone who holds legitimate authority (3) in a high-stakes situation.' ${ }^{15}$ Moral injury for Shay, then, is something that soldiers in battle feel, but it is also about military, and possibly political, leadership. This framing stresses not only the suffering of the individual soldier but also the source of that suffering, arising as it does from the relation between superiors and subordinates in the political conflict known as war.

In general and broad terms, then, dirty hands can be defined as doing wrong in order to effect an important good (or at least, forestall a greater evil), while a moral injury is harm incurred to one's sense of goodness and one's sense of their own ability to strive toward being a good person in the very attempt to do good or carry out an important duty. ${ }^{16}$ Both terms are concerned about the moral status of certain

12 Other theorists also acknowledge this distinction (Sherman op. cit. note $5,77-104)$.

13 I take this notion of striving as central to moral life from Julia Annas's articulation of virtue ethics (Julia Annas, Intelligent Virtue (New York: Oxford University Press, 2009), 18, 52).

14 Shay, op. cit. note 11, xx.

15 Jonathan Shay, 'Casualties', Daedalus 140(3) (2011), 179-88, 183.

16 There are, generally speaking, two main definitions of moral injury within psychology today. There is Shay's, which focuses on betrayal and the relationship of subaltern to superior. The other focuses more on feelings of self-betrayal and a soldier's violation of their own closely held beliefs (Litz, Bret T. et al., 'Moral Injury and Moral Repair in War Veterans: A Preliminary Model and Intervention Strategy', Clinical Psychology Review 29 (2009), 695-706). Shay does eventually agree to the idea of self-betrayal 


\section{Joseph Wiinikka-Lydon}

actions in the political sphere that create dubious effects not only on the world and others but also one's self.

\section{Comparison}

Walzer and Shay's approach to their respective concepts differ in some important ways, however, including what the content of the injury and the dirt actually are, as well as the role of emotions; whether or not one is aware ahead of time that their actions are wrong; and how that affects the potential of repair. I take each of these in turn to gain a better sense of how these two specific, seminal formulations of moral injury and dirty hands relate, before moving on to the more constructive part of this essay.

\subsection{Choice and Awareness of Wrongdoing}

Walzer's politician decides and acts with the knowledge that what she has decided is wrong, even as it is necessary to achieve either a greater good or minimize a greater evil. The politician, then, has evaluative awareness of her action yet chooses it all the same. If she did not, responsibility would give way to more total tragedy, as not unlike Oedipus, the politician would choose without understanding the consequences of those choices. The politician would never know that a moral principle or moral principles had been broken, thus endangering cherished values through ignorance.

Of course, the politician may realize after the fact that what she had decided was wrong, or at least, caused more harm than good, but this would no longer be a case of dirty hands. It would be closer to moral injury. The morally injured subject, unlike the politician who has dirtied her hands, does not know that they will view their actions after the fact as wrong and harmful. There is a shock, even a break, to moral injury where the way one had understood the moral ecology of the world prior to their injurious experience is found retrospectively to be incorrect. This can create a moral cognitive dissonance raising doubt concerning one's continuing ability to strive to be good or whether goodness can occur in the world at all.

as well (Jonathan Shay, 'Moral Injury', Psychoanalytic Psychology 31(2) (2014), 182-91, 182). 


\section{Dirty Hands and Moral Injury}

An example concerning what could be called moral injury comes from Roger Benimoff, an U.S. army chaplain who served in the U.S.-Iraq war and occupation. Benimoff writes of his time in the occupation and details his struggles trying to care for hundreds of soldiers. It is a spiritual reflection as much as a wartime memoir. Benimoff was highly decorated for his work, diagnosed with 'chronic post-traumatic stress disorder', spent time in the hospital for mental health needs, and wrestled with issues of theodicy and his faith. ${ }^{17} \mathrm{He}$ describes himself at certain moments in his book, Faith under Fire, as a 'failed' person, 'spiritually void', and writes in the first person that 'I was angry at everyone, especially those I once held dear to me, God included. I didn't want anything to do with anyone, especially myself. ${ }^{18}$ Although Benimoff does not say he was diagnosed as having clinical moral injury, his discussion of himself as a failed person, afraid of his kids and the noises he made, unable to help his wife in raising the children, no longer being able to be the person he once was, and feeling betrayed by god, can make one feel, characterologically, failed or damaged, which is typical of moral injury. In addition, he entered into the military unaware of such risks inherent in combat. He writes of his experience in the military,

When I first enlisted as a soldier, in 1991, I wanted to go to war; I saw it as the greatest form of service to one's country. It took two deployments for me to recognize that violence simply leads to more violence, that we are poorly equipped as humans to judge who should deserve to die. I hate war. I've seen the spilled blood and the aftermath that soldiers and their families must face for the rest of their lives. It was my job as a chaplain to wade through that aftermath, to try to help them wash away a helplessness that threatened to permanently stain any normal person's consciousness. ${ }^{19}$

This retrospective regret, and even remorse, was just that: an unforeseen violation of one's 'basic moral identity.' 20 His work in the army did not seem negative before or during the action, but only retrospectively, once he reflected on his participation, the occupation, and on war itself.

17 Roger Benimoff and Eve Conant, Faith Under Fire: An Army Chaplain's Memoir (New York: Crown Publishing, 2009), 161.

18 Benimoff and Conant, op. cit. note 17, 178.

19 Benimoff and Conant, op. cit. note 17, 233.

20 Brock and Lettini op. cit. note 5, xiv. 


\section{Joseph Wiinikka-Lydon}

Dirty hands, then, is characterized not only by necessity but also awareness of this situation and action taken in this knowledge. Moral injury, on the other hand, may be seen to arise either from a similar situation where no good courses of action exist or from situations where there are, perhaps, quite good courses of action. Both dirty hands and moral injury may result in guilt, remorse, even something on the line of De Wijze's tragic remorse, yet the morally injured are so injured because they only come to regard what they have done as wrong or as a form of violation after the fact. ${ }^{21}$ In other words, moral injury is something closer to Williams's agent regret in that the morally injured may come to feel it would have been much better not to have acted in the way they did, and even though an objective observer may argue the soldier is not responsible, the soldier is still related to the action in a unique way. ${ }^{22}$

To state this another way, there is a strong epistemological distinction between the two concepts. Dirty hands is more Machiavellian than, say, Oedipal in that the leader has a significant understanding of the situation and the moral dimensions of the choices available to them that empowers the choice to dirty their hands for the greater good (the greater good, at least, in Walzer's understanding). If dirty hands is tragic, it is so because of the inherent moral limitations of politics itself, not necessarily because of the moral deficiencies of the individual actor. Indeed, such remorse is tragic because of a responsible and accurate moral deliberation. ${ }^{23}$ Moral injury, however, at least for Shay, arises when the soldier trusts that the officer or leader will not be careless with the soldier's life, which means the soldier trusts the officer's judgment, at least to some extent. There is then vulnerability inherent in this relationship and in the soldier's epistemological status, a vulnerability that is the ground of one's moral injury. As I will illustrate later, it is this epistemological imbalance between the officer/leader and the soldier,

21 De Wijze defines tragic remorse because he argues other, related terms, such as regret, remorse, or agent-regret, do not capture the specific emotional dimension of dirty hands. It is a specific form of remorse that comes from a responsible agent who takes action that, though shameful, is still necessary. Further fruitful comparison of this concept and moral injury is needed (Stephen De Wijze, 'Tragic Remorse: The Anguish of Dirty Hands', Ethical Theory and Moral Practice 7 (2004), 453-71).

${ }_{22}$ Bernard Williams, 'Moral Luck', in Moral Luck: Philosophical Papers, 1973-1980, (New York: Cambridge University Press, 1981), $20-39,30$.

23 De Wijze op. cit. note 21. 


\section{Dirty Hands and Moral Injury}

and the epistemological dimension of dirty hands and moral injury, that can connect them as concepts.

\subsection{The Injury of Moral Injury}

This, of course, does not mean that soldiers in wartime cannot experience dirty hands in the more traditional sense of consciously choosing the lesser of two evils. Indeed, there are sadly too many opportunities during war for soldiers to knowingly commit wrongdoing out of necessity and duty, whether it is to save the life of a fellow soldier, protect an important area, or as part of the larger goal of victory, which can have its own goods. In such cases, soldiers can still feel they committed a wrong even while doing good.

For the morally injured, their experience can leave a lasting fracture in the morally injured soldier's moral worldview in one or more of three ways. They may no longer be certain that they or the world is capable of 'goodness' or, perhaps, they may feel that the world had never been a place of goodness and that they had deceived themselves or been lied to all this time. One can of course see moral injury as a sacrifice made to help others or the greater good, a sacrifice necessitated by wartime, but it seems that the injured do not readily see it that way. ${ }^{24}$ Consolation, if it comes, will more likely arise from an acceptance of their lack of agency, a lack of responsibility, for what they did in wartime. ${ }^{25}$ To quote Walzer's later work, itself a quote, 'war is hell', and so, soldiers cannot be expected to take on responsibility for the ravages of war, if they behaved in certain parameters, at least. ${ }^{26}$

Indeed, what exactly is injured in moral injury, as far as one's physiology and material psychological substrates, is still a matter of debate. ${ }^{27}$ What the injury feels like, however, is easier to grasp. Moral injury has been described in terms of both guilt and shame, and so is similar in that respect to dirty hands. It is seen as a persistent suffering, which terms such as trauma, that do not usually include the more moral aspects of one's being, do not seem adequate to embody. Moral injury can feel like 'worthlessness, remorse, despair' where the

24 Indeed, this may be an important difference in those morally injured and those who do not seem to be so profoundly affected.

25 Sherman op. cit. note 5.

26 Walzer op. cit. note 8, 22.

27 It is difficult to discuss largely due to the dearth of moral language in psychology (Litz et al. op. cit. note 16, 696). 


\section{Joseph Wiinikka-Lydon}

injured feel they are only a shade of their former self. ${ }^{28}$ Such feelings can result in decreased functionality in one's daily life, a difficulty with relationships, etc. In this sense, what is injured is one's ability to function in society in fulfillment of certain norms. Whatever aspect of a person's physiology or neurochemistry is harmed, the injury can be described at least in part as these feelings, which make it harder to be happy, have sustainable relationships, and to live meaningfully.

\subsection{The Dirt of Dirty Hands}

The feelings of shame and guilt that occur in moral injury are also similar to the experience of dirty hands. There is, however, a distinction made in dirty hands discourse between feeling guilty, that is the first-person sense of one's own culpability, and acknowledging culpability from another standpoint, such as law, universal reason, a generic third-party standpoint, etc. ${ }^{29}$ Although most dirty hands theorists seem to agree that either guilt or regret would result for the individual dirtying their hands, for some such as Nielson, however, that is not the import of the concept. Such philosophers are more concerned with the ethical status of those choices, although they do not doubt that one may feel bad about their dirty choices. Not the experience but whether such choices are truly wrong, and whether they really represent dilemmas, are the central issues of the discourse. ${ }^{30}$ Dirty hands, then, is not universally concerned with questions of wellbeing as they are with moral injury discourse.

For Walzer, however, the phenomenological aspects remain central. ${ }^{31}$ One is dirtied, made somehow impure, and this would seem to affect one's wellbeing. For example, in his seminal 1973 article, 'Political Action: The Problem of Dirty Hands', Walzer uses a number of hypothetical cases, each with a different agent in a different governmental role, to illustrate his understanding of dirty hands. One of these cases centers on a local politician who is also a good man, the kind of person whose integrity would make them a valued public official. In order to realize his potential, however, the individual needs to get elected, yet if our good man has any chance of winning the election,

\footnotetext{
28 Brock and Lettini op. cit. note 5, xv.

29 Stephen De Wijze op. cit. note 21, 458; Kai Nielsen op. cit. note 7, 21.

$30 \quad$ Kai Nielsen op. cit. note 29.

31 Leslie Griffin, 'The Problem of Dirty Hands', Fournal of Religious Ethics 17(1) (1989), 31-61, 32-34.
} 


\section{Dirty Hands and Moral Injury}

he must grease the hands of an unsavory ward boss. ${ }^{32}$ Walzer emphasizes in this example the politician's emotions as particularly salient to understanding what is the 'dirt' in dirty hands. The guilt the politician feels for making the deal with the ward boss is their own acknowledgement that they know they have committed an immoral act, and so, experience the appropriate corollary emotion. In an Aristotelian formulation, they are feeling the right emotion at the right time and for the right reason. And, this 'rightness' reveals a virtuous or excellent character.

Emotion, then, is central for Walzer's understanding of dirty hands. It is, to a significant extent, the feeling of becoming dirty, yet also of believing one is actually dirty and has committed a wrong. ${ }^{33}$ As a result, dirty hands does not have much intelligibility for Walzer without the politician's interior, emotional life. This is true, even though I would argue Walzer would want to reserve the right to evaluate a situation as one that a politician should feel dirty over, whether or not they actually do.

Further, this subjective dimension of dirty hands is important to Walzer because it assures others that, although the politician has committed an immoral act purportedly to achieve a greater good, the politician truly understands the moral stakes involved. She knows the gravity of what she has done and understands the necessity of having done so. And when displaying this remorse publicly, she communicates to the population that a wrong has been committed and that the politician knows it. In other words, the politician is moral, is responsible, and responds to committing immoral acts, even for a good cause, in a way that a good person should. That is, they take responsibility for their actions. The guilt, in other words, is evidence of dirty hands and also evidence of a good character, for only someone with good character will respond to dirty hands appropriately with guilt.

\subsection{Injury versus Dirt}

The two concepts have many qualities that facilitate a fruitful comparison. They deal with decisions and often dilemmas, participation in morally challenging situations, vulnerability concerning moral selfhood, as well as the emotional remainder of engaging in high stakes, often violent situations. To some extent it could seem that

Walzer op. cit. note 9, 166.

Walzer op. cit. note 9, 174. 


\section{Joseph Wiinikka-Lydon}

they cover the same conceptual territory. Moral injury could simply be the experience of having dirty hands, and dirty hands could simply be the way one is morally injured. If applied liberally enough, both terms could overlap considerably. One of the reasons I compare Walzer and Shay, however, is that they help demonstrate the profit in maintaining the separate integrity and comprehensibility of these two concepts.

There is as I have argued an epistemological difference between these concepts, but there is also a phenomenological difference, as well. Although the same emotions are used to describe shame, guilt, and remorse, such universalizing terms can collapse the agentive and moral distinctions to be had between different institutional roles. This insistence is important, because Walzer does not spend time considering the greater ecology of dirty hands and how such decisions will affect those who carry out 'dirty' commands. Shay does, though he is not therapeutically concerned with the wellbeing of commanders. In Shay's writing, it is the chain of command that is the culprit. ${ }^{34}$ What this means, then, is that, although both the dirtied and the injured may feel remorse or guilt, their relationship to the same choices and actions will be different, as will the nature of their responsibility for those actions. The impurity that a politician or decision maker might feel may be more abstract or more intimate, but it will not be, except for rare occurrences, as intimate as the experience of the soldier who, as Brock and Lettini demonstrated, is bodily involved in the act of violence (or, at the very least, is physically active in theaters or environments of violence). One - perhaps a civilian - may feel implicated in war as a part of the political community, but it is the soldier's hand that steadies and fires the gun. ${ }^{35}$ This means that, regardless of how a third party would evaluate the responsibility of all those involved, responsibility must also be seen phenomenologically in moral injury discourse as something that is felt bodily by those involved. There are, then, feelings of morality - the phenomenology of morality - that will differ between the two concepts depending on each individual's worldview, moral disposition, understanding of their role, etc.

There is also a distinction in how experience affects one over the long term. In each case, one approaches an action - even the same action - with different expectations concerning its moral status and how such an action may affect them psychologically. The soldier in the dirty hands scenario may still feel guilt-ridden and even have

34 Shay op. cit. note 16.

35 Brock and Lettini op. cit. note 5. 


\section{Dirty Hands and Moral Injury}

what De Wijze calls tragic remorse, but there is also the potential consolation that what they did they had to in that it allowed for greater goods, for saved lives. The morally injured soldier, however, may be deprived of such a consolation, as both the action and the outcome are perceived as net negatives. Benimoff's case, exampled previously, illustrates how a soldier can feel at least for a time that their work is ultimately ambivalent or even unjust, pulling a caul over any related good works accomplished. Moral injury, then, stands to upend one's assumptions about the nature of the world for the morally injured person, while dirty hands, though tragic, to some degree confirms the subject's sense about politics and that the world as it is might demand wrongdoing from 'good' persons. ${ }^{36}$

This brings forward another distinction between dirty hands and moral injury, that is, what exactly is harmed. For Walzer, there is an impurity that comes from dirty hands. One is 'dirtied' as they have had to sacrifice a moral principle or decide to forsake striving for an image of what it is to be good (e.g., a good person, a good politician, etc.). Moral injury, at least for Shay, is defined by betrayal. A soldier's trust in their leaders is broken by the decisions of those leaders, resulting in a feeling of moral harm. It is possible, of course, that one could feel betrayed in dirtying one's hands. There could be a feeling that one's parents raised one with ideals that could not ultimately withstand the world's harsh realism. They could even feel that society or the universe or even God had somehow betrayed one's trust in a world good enough to maintain the possibility of virtue in politics. Walzer's driving concern, however, concerns the relationship of politics to morality and to counter the Machiavellian understanding of this relationship and the Levinasian provocation that 'politics is opposed to morality.' ${ }^{37}$ For this reason, Walzer focuses on the moral taint that politics can leave on the politician by forcing immoral choices on him or her, and later in his seminal work how one can be morally repaired. ${ }^{38}$ Shay, on the other hand, is concerned not with liberal political philosophy but with therapy, specifically,

36 This is not meant to be an absolute distinction. I can imagine a politician that, even though they do wrongdoing with eyes wide open to create a higher good, may still come through feeling that their character or the world has somehow been lessened. Indeed, it is possible to go into a situation knowing that it will dirty one's hands without fully appreciating beforehand the effect such 'dirt' will have after.

37 Emmanuel Levinas, Totality and Infinity: An Essay on Exteriority, tr. Alphonso Lingis (Pittsburgh, Penn.: Duquesne University Press, 1969), 21.

38 Walzer, op. cit. note 9, 166. 


\section{Joseph Wiinikka-Lydon}

with a form of suffering in soldiers sustained through their role as soldiers. Moral injury, in Shay's conception, is the result of the moral taint that can come from participation in war, but specifically by decisions that are put upon soldiers.

\section{Moral Injury as a Consequence of Dirty Hands}

If we look, then, at political decisions - dirty hands decisions - that have a bearing on political violence or war, then, we might also be able to view moral injury, at least in certain scenarios, as resulting from a leader's dirty hands scenario. This allows for a number of insights regarding dirty hands, particularly Walzer's formulation. For example, a comparison to moral injury helps highlight the fact that Walzer does not extend his understanding of dirty hands beyond the individual as political leader who seems solely responsible for certain decisions. ${ }^{39} \mathrm{He}$ admits that dirty hands may exist in other contexts but argues for the uniqueness of political dirty hands in that that the politician alone both wields violence, which suggests harm to others, and takes responsibility for the broader society on behalf of which he or she makes the hard choices. ${ }^{40}$ Walzer acknowledges that a politician works within institutions, yet his development of dirty hands does not explore what the material location and social relationships involved in politics mean for dirty hands, its scope, and its influence. He does not explore the relationships, norms, and roles of such institutions and how dirty hands relates to this complex context.

As a result, Walzer does not acknowledge that others are involved not only in decision making but also in executing the politician's decision. This makes Walzer's account too individualistic, as S.L. Sutherland argues, focusing on the lone political actor, which is a surprising move for a thinker who has in other works exhibited a strong historical and institutional acuity. ${ }^{41}$ When one looks at the many levels, departments, and institutions required to execute an executive

39 There are, for example, arguments that the dirt should be shared more broadly by the public they represent. See David Archard, 'Dirty Hands and the Complicity of the Democratic Public', Ethical Theory and Moral Practice 16 (2013), 777-90; Martin Hollis, 'Dirty Hands', British Fournal of Political Science 12(4) (1982), 385-98.

40 Walzer op. cit. note 9, 161, 169, 174.

41 S.L. Sutherland, 'Retrospection and Democracy: Brining Political Conduct under the Constitution' in David Shugarman and Paul Rynard (eds.), Cruelty and Deception: The Controversy over Dirty Hands in Politics, (Peterborough: Broadview Press, 2000), 207-27. 


\section{Dirty Hands and Moral Injury}

order in the United States, it seems an odd choice to focus exclusively on the feelings of an executive over the emotional experience of soldiers who actually have to carry out such orders and thereby manufacture the dirt of dirty hands. Indeed, why is the guilt of the politician who orders violence (assuming for the moment that such an order dirties their hands) any more dramatic, morally significant, or intellectually interesting than that of the soldier who must participate in that violence and, sometimes at close range, see the dirt created in real time? Is it not true that it is the soldier who, by having to carry out the order, is more dirtied? Why, then, this privileging of the politician's suffering instead of the soldier's in dirty hands discourse?

Walzer's focus on the individual choice of the individual leader, although perhaps helping to evaluate issues surrounding one particular role in political institutions, determines in its very framing what counts as dirt. This limits a fuller, more accurate accounting of the dirt that high stakes dirty hands decisions create. This approach also ends up eliding the larger institutional ecology in which dirty hands decisions are made and executed. As the quote from Leo Tolstoy's What I Believe, referenced at the beginning of this essay, argues, the judge or leader is rarely also the executioner or soldier, at least not in the modern societies Walzer is referencing. There are always those who must execute the will or policy of leadership. In the case of war, or even torture, there is a hierarchy not only of soldiers or torturers but also of officers, generals, lawyers, policy makers, staff, and others who inform the decision, argue for and against it, give it shape, pick persons to carry it out, and then those who do carry it out, not to mention those who must clean up the mess afterward. ${ }^{42}$ At any node in this ecology, one could feel guilt for their participation or even for failing to sway decision makers in a different direction. When Walzer privileges the lone political leader as the location of dirty hands, he obscures the larger institutional ecology in which decision makers are informed, in which they make decision, and in which those decisions are made reality. By obscuring this ecology, we are not able to fully understand the way in which the 'dirt' in dirty hands is shared by many persons and in many ways. And since it is the politician who knowingly takes on the weight of what must be done, this ends up valorizing the leader. That the politician must atone afterward gives Walzer's

42 Demetris Tillyris op. cit. note 6, 65-55; Henry Shue, 'Torture in Dreamland: Disposing of the Ticking Bomb', Case Western Reserve Fournal of International Law 37(2) (2006), 231-39; Stephen De Wijze, 'Torture and Liberalism', Democratiya 7 (2006), 1-22. 


\section{Joseph Wiinikka-Lydon}

logic a theological structure (a form of political soteriology). ${ }^{43}$ Such emphasis spotlights the leader in a way that can cast a shadow on her subordinates' experience.

Moral injury is important here, as it helps to clarify, at least in part, what this broader ecology is, and by making it part of dirty hands discourse, can aid in correcting any overly individualistic accounts. For example, moral injury signals that one can feel morally impure not only through the kind of consent that Walzer has in mind but also by feeling betrayed by the fact that one's actions, done in good faith, can turn out to be morally ambiguous, at best, and at worse, morally culpable. Such injury arises readily from the complex moral landscape of war, where one's sense of right and wrong can change under the violence and extreme environment that can give rise to extreme dilemmas. There, soldiers can execute actions they thought would be just only to feel afterward that such participation violated some core principle, value, or virtue of their character and moral self-regard.

There is also the further consequence that, when seeing moral injury as a result - part of the dirt - of dirty hands, the decisions of politicians become fraught, not less so. The consequences of a leader's decision will affect the felt character of many subordinates. Not everyone will feel morally injured as a result, but some will, and this fact creates a double culpability in the politician's dirty hands. If political leaders continue to be privileged in such a discourse - and not all theorists follow Walzer on this - then the leader's guilt must be understood not only to involve the immoral act but also the way that such a decision will affect some of his or her own people. This is particularly true for those in the institutions - the overall ecology - of dirty hands who must participate in that decision to different degrees of acquiescence and knowledge about the moral status of a leader's order.

I do not want to push this point too far, however, because Walzer obviously knows this. ${ }^{44}$ The point is that the way Walzer formulates dirty hands elides the experiences of the many who contribute to and are affected by decisions that are made to seem contained on the level

43 See Griffin op. cit. note 31, 32-34, for an overview of the religious connections to Walzer's stance.

44 I say 'obviously', because Walzer published his seminal article on dirty hands near the conclusion of the war between the US and North Vietnam, a war whose media coverage in the United States, and to a significant extent, its cultural debate, focused on the experience of common soldiers. 


\section{Dirty Hands and Moral Injury}

of individual leadership. Part of this is because Walzer is concerned, ultimately, with trying to salvage morality from political necessity, to save morality from Machiavelli's insistence. In doing so, however, his influential formulation of dirty hands discourse obscures an entire dimension of responsibility and culpability in political decision making. When a politician takes on the responsibility for dirty hands, a decision that Walzer sees as freely taken, the politician also makes that decision for those down the hierarchy who must create a plan to execute their orders, those who must command others to execute those orders, and those who actually must execute those orders. Not everyone will feel guilty, of course, but guilt is not something only for those who have consciously take responsibility for war or torture or extreme political situations upon themselves. Moral harms, moral injuries, will be felt, regardless, and in a much wider context of causation than Walzer foresees. In other words, and to follow Tolstoy, the judge cannot act alone. To be a judge (or politician) is to order others to participate in their judgment (or policies), including those who may not have been privy to the judge's reasoning and internal turmoil. It is also to change the world through your rulings and policies, and such change occurs not only in the material structure of the world, but in the minds of those who, by caring out 'dirty' orders, may themselves be made impure. A subordinate may take consolation, as Nancy Sherman argues, from their lessened responsibility as a result, but as Walzer himself argues, even one who feels what has happened is right may still, in cases such as killing, still feel guilty and still feel implicated. ${ }^{45}$

To an extent, Walzer knows this, too. In his discussion of firing squads, he talks about the ways that both the executioner who believes in the rightness of his work and the executioner who is against the death penalty may both feel guilt, the first out of a general human reluctance to kill another human and the later for violating a cherished value. The seed of my gesturing toward a larger ecology, then, is in Walzer's formulation, but his emphasis on the choices of the privileged role of political leadership prevents him from exploring it further. Moral injury can be helpful, as comparison with it can place needed emphasis in dirty hands discourse on this aspect of the ecology in which dirty hands decisions are made and executed. Shay, in particular, with his understanding of moral injury as a betrayal on the part of the military brass helps correct this elision in Walzer's initial definition by focusing on the way that leadership, particularly in a hierarchy and when high stakes are involved, can

Sherman op. cit. note 5; Walzer, op. cit. note 9, 173. 


\section{Joseph Wiinikka-Lydon}

have deeply lasting consequences for subalterns. What Shay's definition illustrates, then, is the way in which political decisions can harm not only a politician's self regard but also those who did not have the privilege of deciding whether or not they would participate in a particular political decision. This can be felt as betrayal down the line. ${ }^{46}$

Differentiating between these experiences is important because there is a large power differential between the political leader and the soldier. There is also a significant difference in their relationship and proximity to the violence or dirt that is ordered. A politician ordering a massacre or torture will not witness the actual violence unless they choose to do so. More likely, the guilt a politician will feel will arise more abstractly from their imagining what has happened but not necessarily from direct experience. The soldier, on the other hand, is the one who must make actually plunge their hands into the muck they have created. On a battlefield, that dirt is visceral and not abstract. Although the leader may feel remorseful, it is no surprise that soldiers, and not politicians, suffer from trauma, and that the military hospitals are filled not with regretful politicians but with the subalterns who carry out the orders. In this sense, Shay's intentional naming of this experience as an 'injury' is helpful, as it underscores the direct experience one has as someone who executes an order.

One final note about the relationship of dirty hands and moral injury. Walzer speaks of discrete decisions about easily delineated issues, such as whether to grease the hand of a contractor or whether or not to torture an individual. I view issues of choice more broadly. Dirty hands need not be limited to an identifiable, discreet moment of choice by a leader, just as moral injury need not be caused by a specific incident. Helping bring a war into being and keeping it going can create plenty of dirt, and just by participating in such wars, one can become morally injured. Moral injury has been diagnosed not only in persons who have actively harmed someone but also from those who handle human remains, who have simply witnessed death's passage or its aftermath, or even those removed from direct killing. ${ }^{47}$ Indeed, what counts as a morally injurious transgression can range widely. ${ }^{48}$ The case of Benimoff is

46 De Wijze also sees dirty hands through the lens of betrayal one makes against 'persons, values, and principles', something that could connect this with his work (Stephen De Wijze op. cit. note 7).

$47 \quad$ Litz et al. op. cit. note 16, 696.

48 Sheila Frankfurt and Patricia Frazier, 'A Review of Research on Moral Injury in Combat Veterans', Military Psychology 28(5) (2016): 318-330. 


\section{Dirty Hands and Moral Injury}

again illustrative as his pain came not from killing but from the experience of participation more generally, of being a caregiver in extreme, violent circumstances. Moral injury, then, underscores the fact that one need not commit a discreet act of violence to feel the harm to one's character and sense of self that extreme conflicts, such as war, can create. The greater ecology of war or political violence, and not only (and perhaps not mainly) discrete acts of will or acquiescence, create lasting moral harm. This also includes dirty hands, which can come about not only from discreet choices but also through general policy making. That participation in politics itself can be dirtying, and not just specific choices, is of course a broader discussion that will have to wait for a later time.

Such ecology, however, is often overlooked in the emphasis on clinical treatment in moral injury discourse. This is surely understandable, as clinicians and behavioral scientists have had to engage first and foremost with the individual and his or her chronic sufferings. Moral injury was created to help give a name to suffering that specific vocabulary, such as post-traumatic stress disorder, did not seem to reflect. At the same time, such a discourse will only be as helpful in treatment as far as it reflects the reality from which moral injury springs. What a comparison with dirty hands begins to do for moral injury discourse is to show the true ecology of vulnerability and suffering that extends not just through to the soldier on the ground but includes those not even within the theater of war. There is a complex ecology to war and extended periods of political violence that create not just subjectivities but intersubjectivities where the suffering of one is related to and possibly generative of another's. Moral subjectivity is inherently moral intersubjectivity and treatments that deal with something so profound as a moral injury require a broader conception of suffering and its nature than what is often available. ${ }^{49}$

\section{Conclusion}

Seeing moral injury as the dirt that dirty hands decisions creates can help expand dirty hands discourse to connect with other discourses, as well as revisit some assumptions within dirty hands discussions, themselves. Seeing dirty hands as part of moral injury, at least Shay's approach to moral injury, can help highlight the suffering

49 Jacob K. Farnsworth et al., 'A Functional Approach to Understanding and Treating Military-Related Moral Injury', Fournal of Contextual Behavioral Science 6 (2017), 391-7. 


\section{Joseph Wiinikka-Lydon}

that occurs not only for the soldier but also for those forced by necessity to order actions that violate their own cherished moral principles. And the choice of war for this essay is apt, as war puts under pressure our moral assumptions and brings out the complexity and indeed tragedy of politics to an unparalleled degree. If there is any human occupation that creates dirt, war and the killing and maiming of others must certainly be quintessential, although certainly not exhaustive. This hopefully will be a step toward expanding concepts and vocabulary, and so the broader analytical language, used to better understand the contours and consequences of some of society's most tragic choices.

JOSEPH WIINIKKA-LYDON (jwl@upce.cz) is a researcher at the Center for Ethics at the University of Pardubice. His recent publications include 'Mapping Moral Injury' in the Journal of Medicine and Philosophy and 'Moral Injury as Inherent Critique' in Political Theology. 